\title{
Impact of Service Quality Dimensions on Patient Satisfaction and Repurchase Intentions in the Public Health Industry
}

\author{
Haryeni $^{1}$, Nofri Yendra ${ }^{2}$ \\ 1Universitas Dharma Andalas, Padang, Indonesia, $\square$ haryeni@unidha.ac.id
}

\begin{abstract}
Submission of high quality services (Servqual) to consumers is the key to success in the service industry. This study aims to determine: (1) the direct effect of service quality (Servqual) dimension on patient satisfaction in the public health industry in Padang City, (2) the direct influence of patient satisfaction on repurchase intentions in the public health care industry in Padang City. The population in this study were residents of Padang City / potential consumers who had already experienced service in the public health care industry in three public hospitals in the city of Padang, namely RS. M. Djamil, Unand Hospital, and RSUD dr. Rasidin. The number of samples used was 150 respondents. Sampling techniques using accidental sampling. The data analysis technique used in testing the hypothesis of this research is SEM analysis with the use of Partial Least Square (PLS) programs. Based on the hypothesis test shows that Assurance has no significant effect on Satisfaction, Emphaty has a significant effect on Satisfaction, Reliable has no significant effect on Satisfaction, Responsibility has no significant effect on Satisfaction, Tangible has no significant effect on Satisfaction, Satisfaction significantly influences Repurchase Intentions. For the R-square value of the Servqual dimension variable for satisfaction of 0.291 , it means that $29.10 \%$ patient satisfaction in the city of Padang can be explained by the servqual dimension variable, and the R-Square value of $28.40 \%$ repurchase intentions can be explained by the variable patient satisfaction.
\end{abstract}

Keywords: Service Quality, Satisfaction, and Repurchase Intentions

\section{Introduction}

Competition has an important place in improving patient quality and satisfaction in health care institutions. When demand exceeds supply, hospitals offer their patients unsatisfactory services because of the idea that patients have no alternative and they will receive current services without conditions, It can be happen in an environment where there is no competition. In the health care industry, hospitals provide the same type of service but they are differentiated based on service quality (Chaniotakis, IE. And Lymperopoulos, C., 2009). Although the relationship between concepts is questionable, there are gaps in the marketing literature that are related to the impact dimensions of service quality on satisfaction, and repurchase intentions, especially in the public health care industry. In particular, the Servqual variable based on Parasuraman et al. (Parasuraman, A. Zeithaml, VA. And Berry, LL., 1988) there are five dimensions of servqual, namely (a) Tangibles, or physical evidence which includes physical facilities (buildings, warehouses etc.), equipment and equipment used ( technology), as well as the appearance of its employees, (b) Empathy, namely the requirement to care, have understanding and knowledge of customers, understand customer needs specifically, and have a comfortable operating time for customers, (c) Reliability includes performance must be appropriate with customer expectations which means timeliness, the same service for all customers, sympathetic attitude and high accuracy, (d) responsiveness includes the willingness to help and provide fast (responsive) and appropriate services to customers with clear information, (e) Assurance, or guarantees and knowledge, namely knowledge, courtesy of compensation and the ability of company employees to grow race a trust customers to the company. The author tries to identify the impact of each servqual dimension variable on satisfaction, and repurchase intentions on patients in the public health care industry in Padang City. This is also in accordance with Cronin and Taylor (1992) who examined four studies regarding the relationship between servqual to customer satisfaction and the result was proven that the two variables had a 
positive/ strong relationship. And Cronin and Taylor (1994) in their research succeeded in proving that customer satisfaction is determined by the customer's assessment of the quality of services provided.

The widely accepted dimension of service quality (SERVQUAL) - tangibles, empathy, reliability, responsiveness, and assurance can be learned to understand its impact on the quality of important outcomes such as patient satisfaction, especially in developing country contexts, where the Indonesian government offers a guarantee program national health. The presence of the BPJS (Social Security Organizing Agency) especially in the health sector is proof that the government is serious in handling public health. According to the Directorate General of Health Services, the Indonesian Ministry of Health in 2016 the number of BPJS Health participant referrals experienced fluctuations. The planned program will ease the burden on the community, but not infrequently the program which has good goals still raises various complaints from the community, especially in terms of BPJS services. Complaints from the public include limited facilities and hospitals. BPJS participants will only get health services in hospitals that have been registered or cooperated with BPJS health so that if there is an unregistered hospital, the use of BPJS cards is not valid.

In this context, the aim of the study was to investigate the effect of service quality dimensions on patient satisfaction, and to identify the effect of satisfaction with repurchase intentions (RI) in the public health care industry. The Urgency of Research is that it can develop marketing knowledge, especially regarding patient satisfaction, and servqual dimensions in three state hospitals in the City of Padang, and can provide additional information and input for hospital management to take steps in solving problems faced in maintaining satisfaction. and the dimensions of service quality (servqual).

\section{Methods}

The population in this study was Padang City residents/ consumers who had used services at three Public Hospitals in the City of Padang, namely M. Djamil Hospital, Unand Hospital and RSUD dr. Rasidin, while the sample is the object of research or the respondent is the easiest to find or accidentally meet, where the respondents were taken as many as 150 respondents. The sampling technique is done using the Accidental Sampling method, which is a method used based on sample selection by selecting elements for sample members, where the subject is the easiest to meet or accidentally meet with researchers, who are considered to represent consumers who have already feel the services to three public hospitals in Padang City from each age group and from each job.

In generally, the elaboration or indicators of the operational definition are indicators of satisfaction variables which are satisfied with hospital medical services and medical services have fulfilled the patient's wishes. The Indicator of servqual variable are consist of Tangible: The hospital has up-todate equipment, the physical facilities of the hospital are visually attractive, the hospital employees look neat, Reliability: The hospital provides services to patients at that time promising to do so when patients experience problems, hospital employees sympathize and can convince their patients, the hospital is accurate in making billing costs to patients, Responsiveness: Hospital employees notify patients when exactly services will be performed, Patients receive prompt service from employees, Hospital employees are always willing to help patients, Assurance: Patients feel safe in their interactions with employees, knowledgeable employees, polite employees, employees receive adequate support from management to do their jobs well, Empathy: Hospital employees give patient attention personally, hospital prioritizes best interest of the patient. The data analysis technique used in testing the hypothesis of this research is SEM analysis with the use of Partial Least Square (PLS) programs. Below shows a picture of the conceptual model: 


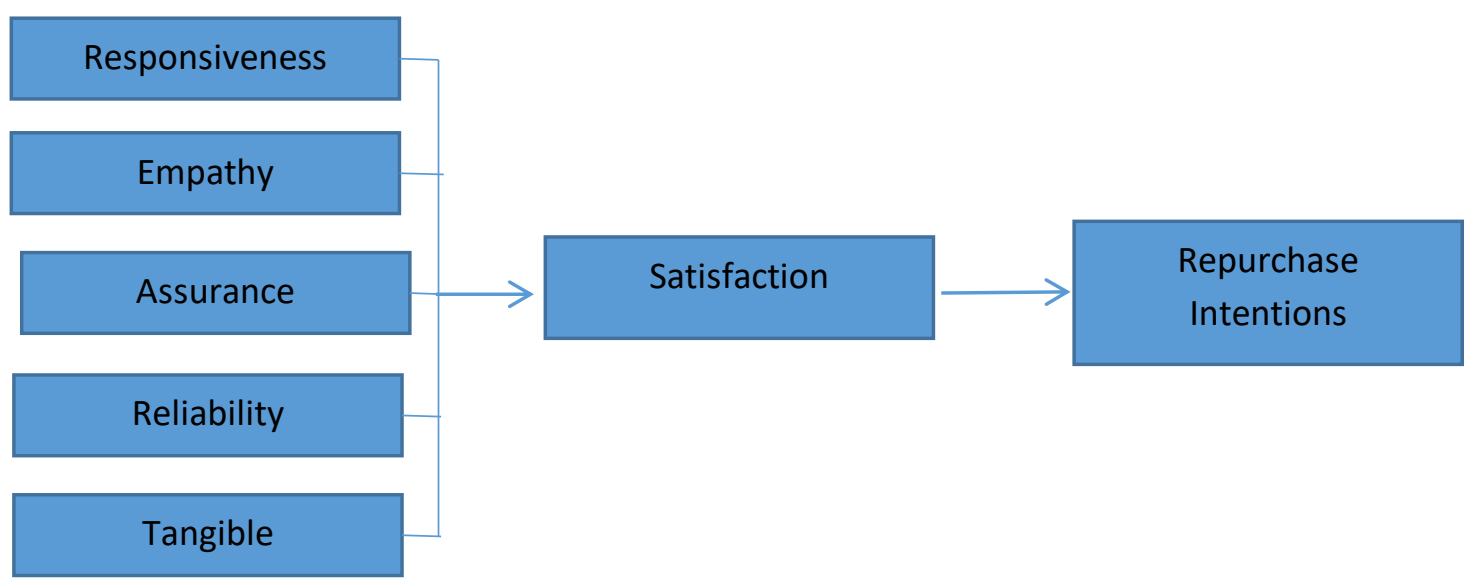

Figure 1 Conceptual Model

In Figure 1 shows the responsiveness effect on satisfaction, empathy influence on satisfaction, assurance to satisfaction, reliability to satisfaction, and tangible to satisfaction, as well as the effect of satisfaction on repurchase intentions.

To get the data needed in this study, the following methods is carried out by Questionnaire, which is making a list of questions submitted to patients at three state hospitals in the city of Padang to obtain data according to the object of research.

\section{Results and Discussion}

Profile of Respondent

From the results of the questionnaire distributed, there are characteristics of the respondents as follows:

Table 1 Profile of Respondents by Gender

\begin{tabular}{clcc}
\hline Num. & Gender & Total & Percentage \\
\hline 1 & Man & 65 & $43,33 \%$ \\
\hline 2 & Woman & 85 & $56,67 \%$ \\
\hline & Total & 150 & $100,00 \%$ \\
\hline
\end{tabular}

Source: Primary Data processed, 2019

Based on Table 1 above, it can be seen that respondents with male sex as many as 65 people and respondents who are female sex there are as many as 85 people.

Table 2 Profile of Respondents by Ages

\begin{tabular}{cccc}
\hline Num. & Ages & Frequency & Percentage \\
\hline 1 & $<20$ & 7 & $4,7 \%$ \\
\hline 2 & $21-30$ & 68 & $45,33 \%$ \\
\hline 3 & $31-40$ & 45 & $30 \%$ \\
\hline 4 & $41-50$ & 20 & $13,33 \%$ \\
\hline 5 & $>51$ & 10 & $6,66 \%$ \\
\hline & Total & 150 & $100 \%$
\end{tabular}

Source: Primary Data processed, 2019 
From Table 2 it is known that the respondents who participated in this study based on age were $<20$ years as many as 7 people, aged $21-30$ years as many as 68 people, age 31 - 40 years as many as 45 people, aged 41 - 50 years as many as 20 people and age 51 years old as many as 10 people. It can be concluded that the age of respondents who dominated ranged from 21-30 years as many as 68 people.

Table 3 Profile of Respondents by Last Education

\begin{tabular}{ccc}
\hline Last Education & Frequency & Percentage \\
\hline Junior High School (SMP) & 10 & $6,66 \%$ \\
\hline Senior High Scholl (SMA) & 72 & $48 \%$ \\
\hline Diploma III & 20 & $13,33 \%$ \\
\hline Bachelor Degree & 31 & $20,66 \%$ \\
\hline Post Graduate & 17 & $11,33 \%$ \\
\hline Total & 150 & $100 \%$ \\
\hline
\end{tabular}

Source: Primary Data processed, 2019

From table 3, it can be seen that the respondent's last education was as many as 10 junior high school students, 72 as high school students, 20 as Diploma III students, 31 as many graduates, and 17 postgraduate students. It can be concluded that the respondents with the most recent high school education dominated the most.

Table 4 Profile of Respondents by Frequency of Use of Services

\begin{tabular}{ccc}
\hline Frequency of Use of Services & Frequency & Percentage \\
\hline $2 \mathrm{x}$ & 68 & $45,33 \%$ \\
\hline $3 \mathrm{x}$ & 50 & $33,33 \%$ \\
\hline$>4 \mathrm{x}$ & 32 & $21,34 \%$ \\
\hline Total & 150 & $100 \%$
\end{tabular}

Source: Primary Data processed, 2019

From table 4 it can be seen that the frequency of respondents using hospital services is the frequency of 2 times as many as 68 people, frequency of 3 times as many as 50 people, and frequency $>4$ times as many as 32 people. It can be concluded that respondents with the frequency of using private hospital services with a frequency of 2 times the most dominate.

\section{Convergent Validity}

The results of data collection obtained from the questionnaire respondents must be tested for validity and reliability. The results of the study are said to be valid, if there are similarities between the data collected and the data that actually occurs in the object under study. Valid means the instrument can be used to measure what you want to measure. Convergent validity of the measurement model with reflexive indicators can be seen from the correlation between each indicator score and the construct score. The individual reflex size is said to be high if it correlates more than 0.70 with the construct that Ghozali (2012) wants to measure.

However, according to Chin in Ghozali (2012) for the initial research phase of the development of a scale measuring the loading values of 0.50 to 0.60 is considered sufficient. The researcher uses the standard loading 0.50 . In this study the Convergent validity test is as follows: 
Table 5 Convergent validity

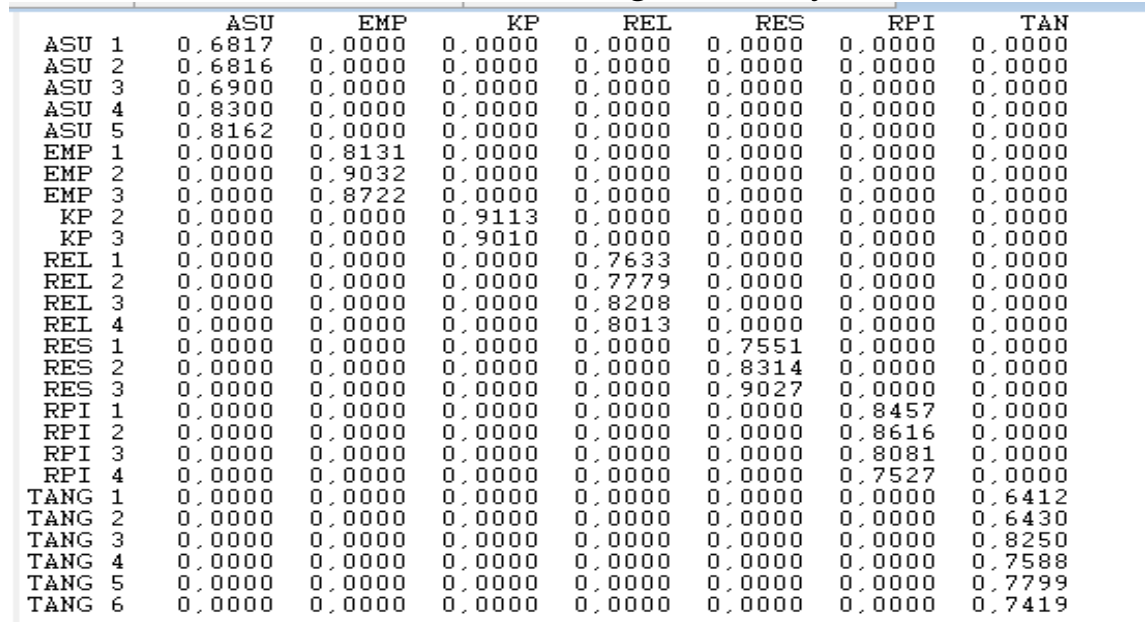

Source: Smart PLS 2.0

Based on the table above shows that the statement of each variable can be said to be valid because the value is $>0.50$, then a further test can be done.

\section{Discriminant Validity}

Discriminant Validity is done through two stages, namely by looking at the cross loading value and comparing between the square of the correlation between the extract and the AVE value or the correlation between the extract and the root AVE. Discriminant Validity is assessed based on cross loading, if other constructs, then this shows that latent constructs predict the size of their block is better than the size of other blocks. It can also be assessed by square root of average variance extracted (AVE), if the AVE square root value of each construct is greater than the correlation value between constructs and other constructs in the model it is said to have good Discriminant Validity values according Ghozali (2012). The variable is declared valid if the Discriminant Validity $>0.50$. In this study discriminant validity tests are as follows:

Table 6 Discriminant Validity

\begin{tabular}{|c|c|}
\hline & AVE \\
\hline \hline ASU & 0,552111 \\
\hline \hline EMP & 0,745911 \\
\hline \hline KP & 0,821124 \\
\hline \hline REL & 0,625873 \\
\hline \hline RES & 0,692089 \\
\hline \hline RPI & 0,669283 \\
\hline TAN & 0,539958 \\
\hline
\end{tabular}

Source: Smart PLS 2.0

Based on the table above shows that the statements of each variable are all declared valid, this is because the value of Discriminant Validity $>0.50$. 


\section{Composite Reliability}

The results of the study are said to be reliable if there are similarities in the data at different times, meaning that instruments that have reliability are instruments that, when used several times to measure the same object, will produce the same data as well. To test whether the instrument is reliable seen from the value of the composite realibility indicator block that measures a construct and also the value of cronbach's alpha.

Table 7 Composite Reliability

\begin{tabular}{|c|c|}
\hline & Composite Reliability \\
\hline \hline ASU & 0,859386 \\
\hline \hline EMP & 0,897859 \\
\hline \hline KP & 0,901774 \\
\hline \hline REL & 0,869900 \\
\hline \hline RES & 0,870259 \\
\hline \hline RPI & 0,889791 \\
\hline TAN & 0,874712 \\
\hline
\end{tabular}

Source: Smart PLS 2.0

Based on the table above shows that the statements of each variable are all declared valid, this is because the Composite Reliability value is $>0.60$.

\section{Structural (inner) Model}

The inner model describes the relationship between latent variables based on substantive theory. Examination of the structural model is done by looking at the R-square value. Assessment of the model with PLS begins by looking at the R-square for each dependent latent variable. Changes in the $\mathrm{R}$-square value can be used to assess the influence of latent dependent variables whether they have a substantive effect. The higher the R-square value, the greater the ability of the independent variable to explain the dependent variable so that the structural equation is better. In this study the Structural (Inner) Model is as follows:

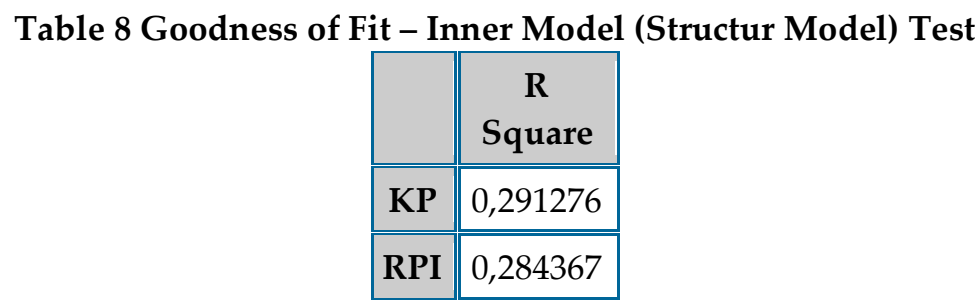

Source: Smart PLS 2.0

Based on table 8, shows the R-square value of the Servqual dimension variable to Satisfaction of 0.291 , the satisfaction variable to the repurchase intentions variable of 0.284 . The higher the R-square value, the greater the ability of the independent variable to explain the dependent variable so that the structural resistance is better.

\section{Hypothesis Testing}

The proposed hypothesis can be tested from looking at the magnitude of the T-statistic value. Because PLS does not assume normality and data distribution, PLS uses a non parametric test to determine the significant level of pathcoefficient, where the value of $\mathrm{t}(\mathrm{t}$-statistics) is generated by running a bootstraping algorithm on SmartPLS 2.0. Its usefulness to determine whether or not the 
hypothesis proposed is accepted. The hypothesis will be accepted if the t-statistic value exceeds 1.96 Ghozali (2012). In this study the Hypothesis Test is as follows:

Table 9 Hypothesis Testing

Path Coefficients (Mean, STDEV, T-Values)
\begin{tabular}{|c|c|c|c|c|}
\hline & Original Sample (0) & Sample Mean (M) & Standard Deviation (STDEV) & Standard Error (STERR) \\
\hline ASU > KP & $-0,037535$ & 0,028693 & 0,130330 & 0,130330 \\
\hline EMP > KP & 0,225900 & 0,203587 & 0,108699 & 0,108699 \\
\hline KP > RPI & 0,533261 & 0,539076 & 0,054324 & 0,054324 \\
\hline REL - > KP & 0,100484 & 0,090147 & 0,116916 & 0,116916 \\
\hline RES $>$ KP & 0,163248 & 0,151733 & 0,141665 & 0,141665 \\
\hline TAN $>$ KP & 0,186495 & 0,192824 & 0,139172 & 0,139172 \\
\hline
\end{tabular}

\begin{tabular}{|c|c|}
\hline & T Statistics (|O/STERR |) \\
\hline ASU $\rightarrow$ KP & 0,287999 \\
\hline EMP $\rightarrow$ KP & 2,078228 \\
\hline KP $\rightarrow$ RPI & 9,816316 \\
\hline REL $>$ KP & 0,859452 \\
\hline RES $>$ KP & 1,152355 \\
\hline TAN $>$ KP & 1,340037 \\
\hline
\end{tabular}

Table of contents

Source: Smart PLS 2.0

Based on the results of hypothesis testing found in table 9 above it can be concluded that the following: Assurance does not have a significant effect on satisfaction, this is due to the value of the $\mathrm{T}$ statistic $(0.287)<\mathrm{t}$-statistical value (1.96). Then Ha is Rejected and H0 is Accepted, Emphaty has a significant effect on Satisfaction, this is due to the value of $\mathrm{T}$ statistic $(2,078)>\mathrm{t}$-statistic value $(1.96)$. Then Ha is accepted and $\mathrm{H} 0$ is rejected, reliable does not have a significant effect on satisfaction, this is due to the value of the $\mathrm{T}$ statistic $(0.859)<\mathrm{t}$-statistic value (1.96). Then Ha Rejected and H0 Accepted, Responsibility does not have a significant effect on Satisfaction, this is due to the value of the T statistic $(1,152)<\mathrm{t}$-statistical value (1.96). Then Ha is Rejected and H0 is Accepted, Tangible has no significant effect on Satisfaction, this is due to the value of the T statistic $(1,340)<$ t-statistic value (1.96). Then Ha is Rejected and H0 is Accepted, Satisfaction has a significant effect on Repurchase Intentions, this is due to the value of T statistic $(9,816)>t$-statistic value (1.96). Then Ha is accepted and $\mathrm{H} 0$ is rejected.

\section{Conclusions}

Based on the results of research on the Impact of Service Quality Dimensions on Patient Satisfaction and Repurchase Intentions in the Public Health Industry, the results are summarized as follows: Based on the hypothesis test shows that Assurance has no significant effect on Satisfaction, From this result, Ho is accepted and Ha is rejected. This means that assurance does not have a significant effect on patient satisfaction. Emphaty has a significant effect on Satisfaction Satisfaction, From this result means Ho is rejected Ha accepted. This means that the higher the empathy created by the hospital will increase patient satisfaction. Responsibility does not significantly influence Satisfaction, From this result, Ho is accepted and Ha is rejected. This means that responsibility has no significant effect on customer satisfaction. Tangible does not have a significant effect on Satisfaction, From this result, Ho is accepted and Ha is rejected. This means that tangible has no significant effect on patient satisfaction. Satisfaction has a significant effect on Repurchase Intentions, From this result means Ho is rejected Ha accepted. This means that the higher satisfaction felt by patients will increase repurchase intentions. The benefits of this study is developing knowledge about marketing, especially regarding patient satisfaction, dimensions of service quality and patient loyalty, Become additional 
information and input for hospital management to take steps in solving problems faced in maintaining satisfaction and loyalty of patients, Providing information and additional knowledge to other researchers who want to conduct research and discussion on the same problem in the future.

\section{References}

Aagja, J. P. and Garg, R. (2010). Measuring perceived service quality for public hospitals (PubHosQual) in the Indian context. International Journal of Pharmaceutical and Healthcare Marketing, 4(1), 60 - 83.

Anbori, A. Ghani, SN. Yadav, H. Daher, AM. and Su, TT. (2010). Patient satisfaction and loyalty to the private hospitals in Sana'a, Yemen. International Journal for Quality in Health Care, 22(4), 310315.

Andaleeb, SS. and Millet, I. (2010). Service experiences in hospitals in Bangladesh: are there gender inequities?. International Journal of Health Care Quality Assurance, 23(6), 591 - 606.

Butt, MM. and Run, EC. (2010). Private healthcare quality: applying a SERVQUAL model. International Journal of Health Care Quality Assurance, 23(7), 658-673.

Camilleri, D. and O'Callaghan, M. (1998). Comparing public and private hospital care service quality. International Journal of Health Care Quality Assurance, 11(4), 127 - 133.

Chaniotakis, IE. and Lymperopoulos, C. (2009). Service quality effect on satisfaction and word of mouth in the health care industry. Managing Service Quality, 19(2), 229-242.

Chowdhary, N. and Prakash, M. (2007), Prioritizing service quality dimensions, Managing Service Quality, 17(5), 493 - 509.

Cronin, JJ. and Taylor, SA. (1992). Measuring service quality: a re-examination and extension. Journal of Marketing, 56, 55-68.

Djarwanto. (2012). Statistik Induktif. Edisi kelima, BPFE: Yogyakarta.

Ehigie, BO. (2006). Correlates of customer loyalty to their bank: a case study in Nigeria. The International Journal of Bank Marketing, 24(7), 494- 508.

Hu, LT. and Bentler, PM. (1999). Cut off criteria for fit indexes in covariance structure analysis: conventional criteria versus new alternatives. Structural Equality Modeling, 6(1), 1-55.

Işık, O. Tengilimoğlu, D. and Akbolat, M. (2011). Measuring health care quality with the SERVQUAL method: a comparison in public and private hospitals. HealthMED, 5(6), 921-1930.

Jabnoun, N. and Al-Tamimi HAH, (2003). Measuring perceived service quality at UAE commercial banks. International Journal of Quality \& Reliability Management, 20(4), 458 - 472.

Jun, M., Yang, Z. and Kim, D. (2004), Customers' perceptions of online retailing service quality and their satisfaction. International Journal of Quality \& Reliability Management, 21(8), 817- 840

Kandampully, J. and Suhartanto, D. (2000). Customer loyalty in the hotel industry: the role of customer satisfaction and image. International Journal of Contemporary Hospitality Management, 12(6), $346-351$

Karatepe, OM. Avci, T. and Tekinkus, M. (2005). Measuring service quality of banks: scale development and validation. Journal of Retailing and Consumer Services, 12(5), 373-383.

Kitapci, O. Akdogan, C. Dortyol, IT. (2014). The Impact of Service Quality Dimensions on Patient Satisfaction, Repurchase Intentions and Word-of-Mouth Communication in the Public Healthcare Industry. Procedia - Social and Behavioral Science, 148, 161 - 169.

Kuei, C. and Lu, M.H. (1997), An integrated approach to service quality improvement, International Journal of Quality Science, 2(1), 24-36.

Kuo, Y. Wu, C. and Deng, W. (2009). The relationship among service quality, perceived value, customer satisfaction, and post-purchase intention in mobile value-added services. Computer in Human Behavior, 25, 887-896.

Ladhari, R. (2009). A review of twenty years of SERVQUAL research. International Journal of Quality and Service Science, 1(2), 172-198.

Lang, B. (2011). How word of mouth communication varies across service encounters. Managing Service Quality. 21(6), 583-598. 
Long, M. and McMellon, C. (2004). Exploring the determinates of retail service quality on the internet, Journal of Service Marketing, 18(1), 78-90.

Manaf, NHA. (2005). Quality management in Malaysian public health care. International Journal of Health Care Quality Assurance, 18(3), 204 - 216.

Mayfield, J. and Mayfield, M. (2008). The creative environment's influence on intent to turnover, Management Research News, 31(1), 41-56.

Mazzarol, T. Sweeney, JC. and Soutar, GN. (2007). Conceptualizing word-of-mouth activity, triggers and conditions: an exploratory study. European Journal of Marketing, 41(11/12), 1475 - 1494

Mei, AWO. Dean, AM and White CJ. (1999). Analysing service quality in the hospitality industry, Managing Service Quality, 9(2), 136 - 143.

Mels, G. Boshoff, C. and Nel, D. (1997). The dimensions of service quality: the original European perspective revisited. Service Industries Journal, 17(1), 73-89.

Murray, D. and Howat, G. (2002). The relationship among service quality, value, satisfaction, and future intentions of customers at an Australian sports and leisure centre. Sport Management Review, 5, 25-43.

Murray, K. (1991). A test of services marketing theory: consumer information acquisition activities, Journal of Marketing, 55, 10-25.

Nadiri, H. and Hussain, K. (2005). Perceptions of service quality in North Cyprus hotels. International Journal of Contemporary Hospitality Management, 17(6), 469-480.

O'Neill, M. Watson, H. and McKenna, M. (1994). Service Quality in the Northern Ireland Hospitality Industry, Managing Service Quality, 4(3), 36 - 40.

Parasuraman, A. Zeithaml, VA. and Berry, LL. (1988). SERVQUAL: A multiple item scale for measuring consumer perceptions of service quality, Journal of Retailing, 64(1), 12-43.

Parasuraman, A. Zeithaml, VA. and Berry, LL. (1991). Refinement and reassessment of the SERVQUAL scale. Journal of Retailing, 67(4), 420-50.

Phillips, WJ. Wolfe, K. Hodur, N. and Leistritz, FL. (2011). Tourist word of mouth and revisit intentions to rural tourism destinations: A case of North Dakota, USA. International Journal of Tourism Research, 13(6), 600-12

Pizam, A. and Ellis, T. (1999). Customer satisfaction and its measurement in hospitality enterprises. International Journal of Contemporary Hospitality Management, 11(7), 326-339.

Poolthong, Y. and Mandhachitara, R. (2009). Customer expectations of CSR, perceived service quality and brand effect in Thai retail banking. International Journal of Bank Marketing, 27(6), 408-427.

Qin, H. Prybutok, VR. and Zhao, Q. (2010). Perceived service quality in fast-food restaurants: empirical evidence from China, International Journal of Quality \& Reliability Management, 27(4), $424-437$

Redman, T. and Mathews, B. P. (1998), Service quality and human resource management: A review and research agenda, Personnel Review, 27 (1), 57-77

Repo, KL. (1999), Word-of-mouth communication in the hospitality industry, Swedish School of Economics and Business Administration Research Reports.

Saunders, S.G. (2008), Measuring and applying the PAKSERV service quality construct:Evidence from a South African cultural context. Managing Service Quality, 18(5), 442 - 456.

Sieberer, UR. Freeman, J. Kokonyei, G. Thomas, CA. and Erhart M. (2009). School as a determinant for health outcomes - a structural equation model analysis. Health Education, 109(4), 342-356.

Svensson, G. (2006). New aspects of research into service encounters and service quality, International Journal of Service Industry Management, 17, 245-57.

Sweeney, JC. Soutar, GN. and Mazzarol T. (2008). Factors influencing word of mouth effectiveness: Receiver perspectives, European Journal of Marketing, 42(3/4), 344-364.

Tsiotsou, R. (2006). The role of perceived product quality and overall satisfaction on purchase intentions. International Journal of Consumer Studies, 30(2), 207-217. 
Tsoukatos, E. and Rand, GK. (2006). Path analysis of perceived service quality, satisfaction and loyalty in Greek insurance. Managing Service Quality, 16(4), 501-519.

Wang, X. (2011). The effect of inconsistent word-of-mouth during the service encounter. Journal of Service Marketing, 25(4), 252-259.

Wang, Y. and Lo, HP. (2002). Service quality, customer satisfaction and behaviour intentions: Evidence from China's telecommunication industry. Info, 4(6), 50-60.

White, J.C., Varadarajan, P.R. and Dacin, P.A. (2003), Market situation interpretation and response: the role of cognitive style, organizational culture, and information use, Journal of Marketing, 67(3), 63-79.

Woodside, AG. Frey, LL. and Daly, RT. (1989). Linking service quality, customer satisfaction, and behavioral intention, Journal of Health Care Marketing, 9(4), 5-17.

Yang, Z. and Peterson, RT. (2004). Customer perceived value, satisfaction, and loyalty: The role of switching costs, Psychology \& Marketing, 21(10), 799-822.

Yeşilada, F. and Direktör E. (2010). Health care service quality: A comparison of public and private hospitals. African Journal of Business Management, 4(6), 962-971.

Zairi, M. (2000). Managing customer satisfaction: A best practice perspective. The TQM Magazine, 12(6), 389-394.

Zhou, L. Zhang, Y. and Xu, J. (2002). A Critical Assessment of SERVQUAL's Applicability in the Banking Context of China, Asia Pacific Advances in Consumer Research, Association for Consumer Research, 5, 14-21. 